GRASAS Y ACEITES 67 (3)

July-September 2016, e149

ISSN-L: 0017-3495

doi: http://dx.doi.org/10.3989/gya.0441161

\title{
Effect of the distribution of saturated fatty acids in the melting and crystallization profiles of high-oleic high-stearic oils
}

\author{
M.A. Bootello, R. Garcés, E. Martínez-Force and J.J. Salas ${ }^{\circledR}$ \\ Instituto de la Grasa, CSIC, Sevilla, Spain. \\ Instituto de la Grasa (CSIC). Ctra. de Utrera, km. 1. Campus Universitario Pablo de Olavide. Edificio 46. C.P. 41013, Seville (Spain) \\ Corresponding author: jjsalas@ig.csic.es
}

Submitted: 06 April 2016; Accepted: 16 May 2016

SUMMARY: The composition and distribution of fatty acids in triacylglycerol (TAG) molecules are commonly considered as factors that determine the physical properties of a given oil or fat. The distribution of any fatty acid in fats and oils can be described through the $\alpha$ coefficient of asymmetry, which can be calculated from the TAG composition and fatty acid composition of the $s n-2$ position of the TAGs determined through lipase hydrolysis. High-oleic high-stearic oils and fats are considered stable and healthy, and they are good substitutes for hydrogenated vegetable oils and palm fractions in many food products, such as spreads and confectionery. Here, different high-oleic high-stearic acid oils were formulated which contained different distributions of saturated fatty acids in their TAGs, while maintaining a similar fatty acid composition. The aim of this work was to discuss the possibility of using the $\alpha$ coefficient to predict the physical properties of fats in function of their chemical composition and their melting and crystallization behavior as examined by differential scanning calorimetry.

KEYWORDS: Asymmetry coefficient; Differential scanning calorimetry; High-oleic high-stearic fats; Melting-crystallization profile; Solid fat content

RESUMEN: Efecto de la distribución de los ácidos grasos saturados en los perfiles de fusión y cristalización de los aceites alto esteárico alto oleico. La composición y distribución de los ácidos grasos en las moléculas de triglicéridos se consideran factores determinantes en las propiedades físicas de los aceites y grasas. La distribución de ácidos grasos en un determinado aceite o grasa puede caracterizarse mediante un coeficiente de asimetría $\alpha$, calculado a partir de las composiciones de triglicéridos y de ácidos grasos en la posición $s n$-2 de la molécula de triglicérido mediante hidrólisis con lipasa. El aceite de girasol alto oleico-alto esteárico es una grasa estable y saludable, adecuada para reemplazar a los aceites vegetales hidrogenados y fracciones de palma en muchos productos alimentarios, como grasas plásticas y grasas de confitería. En el presente trabajo, se formularon diferentes aceites alto oleico-alto esteárico con diferente distribución de los ácidos grasos saturados en sus triglicéridos, aunque manteniendo una composición similar de ácidos grasos. Los perfiles de fusión y cristalización de estas grasas se estudiaron mediante calorimetría diferencial de barrido. El principal objetivo de este trabajo fue analizar la posibilidad de usar el coeficiente $\alpha$ para estimar las propiedades físicas de las grasas a partir de estos resultados.

PALABRAS CLAVE: Calorimetría diferencial de barridos; Coeficiente de asimetría; Contenido de grasa sólida; Grasas alto oleico-alto esteárico; Perfil de fusión- cristalización

Citation/Cómo citar este artículo: Bootello MA, Garcés R, Martínez-Force E, Salas JJ. 2016. Effect of the distribution of saturated fatty acids in the melting and crystallization profiles of high-oleic high-stearic oils. Grasas Aceites 67 (3): e149. doi: http://dx.doi.org/10.3989/gya.0441161.

Copyright: (c) 2016 CSIC. This is an open-access article distributed under the terms of the Creative Commons Attribution-Non Commercial (by-nc) Spain 3.0 Licence. 


\section{INTRODUCTION}

The physical properties of oils and fats largely determine their uses and applications (Gunstone, 2002). Among the factors determining the melting and crystallization profiles of a fat, the most determinant appear to be the fatty acid composition and the distribution of saturated fatty acids in the triacylglycerol (TAG) molecules. Accordingly, a model of the fatty acid distribution has been proposed for vegetable oils (Van der Wal, 1960) based on the 1,3 random 2-random principle and it is thought to predict the TAG composition from the data available regarding the fatty acids present at the $s n-1,3$ and $s n-2$ positions of a given oil.

However, this model is based on an assumption that does not hold true in most species, i.e. that the $s n-1$ and $s n-3$ positions of TAGs are occupied by an identical proportion of saturated and unsaturated fatty acids. This principle was shown to be false by stereo-chemical studies carried out on oils from different species (Takagi and Ando, 1995; Santinelli et al., 1992), reflecting the different specificities of the enzymes involved in TAG biosynthesis that carry out the successive acylation of glycerol-3P: glycerol-3P-acyltransferase (GPAT), lysophosphatidate acyltransferase (LPAAT) and diacylglycerol acyltransferase (DAGAT) (Ohlrogge and Browse, 1995). Since each of these enzymes displays a preference for different substrates, certain pairs of fatty acids are favored at the expense of others, according to the joint specificity of GPAT and DAGAT, and asymmetric TAGs with regards to the $s n-1,3$ positions which are produced. These deviations from the model of Van der Wal can be quantified using the so called $\alpha$ coefficient, which is defined as a coefficient of asymmetry given by the fatty acid content in the $s n-1$ position of TAGs in proportion to the total content of the same fatty acid at positions $s n-1$ and $s n-3$ (Martínez-Force et al., 2004). Therefore, this coefficient ranges from 0 in the case of totally asymmetric oils to 0.5 in symmetric TAG mixtures that fit Van der Wal's model.

In reference to saturated fatty acids $\left(\alpha_{\text {sat }}\right)$, the $\alpha$ coefficient changes from one plant species to another. Likewise, it is also modified in function of the level of saturated fatty acids and other factors, such as the ratio between oleic and linoleic acid in different sunflower fatty acid mutants (MartínezForce et al., 2009). Here, we studied different collections of oils containing similar fatty acid compositions but different distributions of the saturated fatty acids in their TAG molecules and hence, different $\alpha_{\text {sat }}$ coefficients, which were calculated in function of their TAG composition. These oils were of the high-oleic high-stearic type, which are of interest given their stability and possible application as alternatives to the undesirable palm, lauric and hydrogenated trans fats in confectionery (Fernández-
Moya et al., 2005; Pleite et al., 2006; Flickinger and Huth, 2004; Wassell and Young, 2007; List, 2004; Legrand and Rioux, 2015). The melting and crystallization behavior are the most important properties of confectionery and plastic fats (Narine and Marangoni, 1999; Marangoni, 2002; Smith et al., 2013) and thus, the phase transitions of these oils were studied by differential scanning calorimetry (DSC). Thus, the possibility of using the $\alpha_{\text {sat }}$ factor to predict the physical properties of oils and fats is discussed in function of the results.

\section{MATERIALS AND METHODS}

\subsection{Oil preparation}

The oil and fats described in this work were prepared by mixing oils from different high-oleic highstearic sunflower mutants and when necessary, with oil fractions with the appropriate TAG composition. The saturated fatty acid levels and the $\alpha_{\text {sat }}$ values were adjusted by adding stearins enriched in disaturated TAGs, or oleins having high levels of monosaturated TAGs to the mixtures. These stearins and oleins were obtained from high-oleic high-stearic sunflower oils by solvent fractionation. Special care was taken to keep the fatty acid composition constant within each oil series.

\subsection{TAG analysis by GC}

Approximately $5 \mathrm{mg}$ of oil were dissolved in $1.8 \mathrm{~mL}$ of heptane in glass vials and TAGs were analyzed according to Fernández-Moya et al. (2000). The analysis of TAGs was carried out by injecting $1 \mu \mathrm{L}$ aliquots of these solutions into the GC system, an Agilent 6890 gas chromatography apparatus (Palo Alto, CA, USA) using hydrogen as the carrier gas. The injector and detector temperatures were both $370{ }^{\circ} \mathrm{C}$, the oven temperature was $335^{\circ} \mathrm{C}$, and a head pressure gradient from 70 to $120 \mathrm{kPa}$ was applied. The gas chromatography column was a Quadrex Aluminium-Clad 400-65HT (30 m length, $0.25 \mathrm{~mm}$ i.d., $0.1 \mu \mathrm{m}$ film thickness; Woodbridge, CT, USA), using a linear gas rate of $50 \mathrm{~cm} \cdot \mathrm{s}^{-1}$, a split ratio 1:80 and a flame ionization detector (FID). The TAG species were identified according to Fernández-Moya et al. (2000) and each was quantified by applying the previously reported correction factors (Carelli and Cert, 1993).

\subsection{Analysis of fatty acid methyl esters}

Fatty acid moieties of TAGs were transmethylated into fatty acid methyl esters by treating the oils for $1 \mathrm{~h}$ at $80^{\circ} \mathrm{C}$ with $3 \mathrm{~mL}$ of methanol/toluene/sulfuric acid (88/10/2 v/v/v) (Garcés and Mancha, 1993). The resulting methyl esters were then extracted twice with $1 \mathrm{~mL}$ of heptane and analyzed by GC in a 
Hewlett-Packard 6890 gas chromatography apparatus (Palo Alto, CA, USA). The column used was a Supelco SP-2380 fused silica capillary column (30 m length; $0.25 \mathrm{~mm}$ i.d.; $0.20 \mu \mathrm{m}$ film thickness: Bellefonte, PA, USA) with hydrogen as the carrier gas at $28 \mathrm{~cm} \cdot \mathrm{s}^{-1}$. The detector and oven were maintained at a temperature of $200^{\circ} \mathrm{C}$ and $170{ }^{\circ} \mathrm{C}$, respectively. The different methyl esters were identified by comparing their retention times with those of known standards.

\subsection{Calculation of the $\alpha$ coefficient}

The distribution of the saturated fatty acids at the external $s n-1$ and $s n-3$ positions of TAGs was calculated using the $\alpha$ coefficient of asymmetry. This coefficient was determined as the $\alpha$ coefficient of the SatUnsSat/SatUnsUns ( $\alpha$ SUS/SUU) TAGs, as recommended for vegetable oils with low saturated fatty acid contents in the $s n-2$ position (MartínezForce et al., 2004). A coefficient below 0.5 implies that there are more saturated fatty acids at $s n-1$ than at the $s n-3$ position, or vice versa. When the saturated fatty acid content of the oil is very high, $\alpha$ approximates to 0.5 because the whole enzymatic system is completely filled with saturated fatty acids. For example, if $\alpha$ is 0.26 for an oil, 26\% of the saturated content is found in one external TAG position and $74 \%$ at the other.

\subsection{Calorimetric analysis by DSC}

The melting and crystallization profiles of the different oils were determined by differential scanning calorimetry (DSC) in a Q2000 calorimeter (TA instruments, New Castle, DE, USA) which was calibrated using a metal indium. Samples were prepared by transferring approximately $7 \mathrm{mg}$ of the melted oils to aluminium pans and the exact weight of the pans and the sample was then determined in an electronic microbalance Sartorius M2P (Sartorius AG, Goettingen, Germany).

Melting intervals were determined by heating the oils to $90^{\circ} \mathrm{C}$ for $5 \mathrm{~min}$, then ramping the temperature down to $-40{ }^{\circ} \mathrm{C}$ at a rate of $20^{\circ} \mathrm{C} / \mathrm{min}$ with temperature modulation amplitude of $\pm 0.8^{\circ} \mathrm{C}$ every 60 seconds and finally heating at $5{ }^{\circ} \mathrm{C} / \mathrm{min}$ to $90^{\circ} \mathrm{C}$. Modulated DSC (MDSC) was applied to study the thermal transitions of the oil blends. This technique allows the separation of overlapping phenomena such as melting/recrystallization and subtle transitions without loss of resolution (Verdonck et al., 1999; Samyn et al., 2012). By using MSDC, it is possible to obtain reversing and non-reversing components of a thermal event (Ping Tal et al., 2015). In the present work, we used only a reversible heat flow signal to study the melting behavior of oil samples.

The solid fat content (SFC) was determined by continuous integration of the DSC melting curves using the TA universal analysis software. Moreover, the course of crystallization was obtained by completely melting the oils at $90{ }^{\circ} \mathrm{C}$ for $5 \mathrm{~min}$, and by collecting the heat flow data of decreasing temperature up to $-70{ }^{\circ} \mathrm{C}$ at a rate of $10^{\circ} \mathrm{C} / \mathrm{min}$. The integration and treatment of the data was carried out with the TA universal analysis program supplied by the manufacturer of the DSC system. As stated, integration of the melting profiles was accomplished using reversible heat flow data, which excluded any irreversible transitions such as polymorphic transformations that could take place during the melting temperature ramp.

\section{RESULTS AND DISCUSSION}

In the present work, oils with different saturated fatty acid distributions at the $s n-1$ and $s n-3$ positions of TAGs were prepared by mixing sunflower oils and sunflower oil fractions enriched in disaturated TAGs. Within each series, the oils investigated contained approximately the same composition of saturated fatty acids but a different distribution between the 1 and 3 positions of the TAG. These differences in saturated fatty acids can be quantified through the so called $\alpha_{\text {sat }}$ (or simply $\alpha$ ) coefficient. Such variation is usually found in oils from different species and it is caused by the different substrate specificity of the enzymes participating in TAG biosynthesis. Thus, the TAGs in rice oil have a symmetric saturated fatty acid distribution with an $\alpha$ value of 0.49 , whereas the high asymmetry in walnut oil TAGs is reflected by an $\alpha$ value of 0.04 (MartínezForce et al., 2004). The distribution of fatty acids was also demonstrated to be a function of the fatty

TABLE 1. Fatty acid composition of oils from the different series studied $^{\mathrm{a}}$

\begin{tabular}{|c|c|c|c|c|c|c|c|c|}
\hline & & \multicolumn{6}{|c|}{ Fatty acid composition (\%) } & \multirow{2}{*}{$\begin{array}{c}\text { Total } \\
\text { Saturated }\end{array}$} \\
\hline & & $\mathbf{P}$ & St & $\mathbf{O}$ & $\mathbf{L}$ & $\mathbf{A}$ & B & \\
\hline \multirow{6}{*}{ 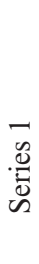 } & Oil 1.1 & 5.2 & 17.6 & 70.1 & 4.1 & 1.3 & 1.7 & 25.8 \\
\hline & Oil 1.2 & 5.2 & 18.4 & 68.6 & 4.2 & 1.6 & 2.2 & 27.3 \\
\hline & Oil 1.3 & 5.3 & 18.4 & 68.5 & 4.2 & 1.6 & 2.0 & 27.4 \\
\hline & Oil 1.4 & 5.4 & 18.5 & 68.2 & 4.3 & 1.6 & 2.1 & 27.6 \\
\hline & Oil 1.5 & 5.6 & 18.4 & 68.2 & 4.3 & 1.6 & 2.0 & 27.6 \\
\hline & Oil 2.1 & 5.3 & 21.5 & 65.4 & 4.4 & 1.5 & 2.0 & 30.3 \\
\hline \multirow{3}{*}{ 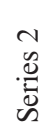 } & Oil 2.2 & 5.6 & 21.0 & 65.7 & 4.3 & 1.5 & 2.0 & 30.1 \\
\hline & Oil 2.3 & 5.9 & 20.8 & 65.5 & 4.3 & 1.5 & 2.1 & 30.3 \\
\hline & Oil 2.4 & 6.1 & 21.0 & 65.2 & 3.8 & 1.6 & 2.3 & 31.0 \\
\hline \multirow{3}{*}{$\begin{array}{l}m \\
\mathscr{0} \\
\stackrel{0}{0} \\
\tilde{D}\end{array}$} & Oil 3.1 & 4.5 & 25.8 & 61.9 & 3.5 & 1.6 & 2.6 & 34.6 \\
\hline & Oil 3.2 & 4.2 & 25.8 & 62.3 & 3.4 & 1.6 & 2.8 & 34.3 \\
\hline & Oil 3.3 & 4.0 & 25.6 & 63.0 & 3.4 & 1.4 & 2.7 & 33.6 \\
\hline
\end{tabular}

${ }^{a} \mathrm{P}$, palmitic acid; St, stearic acid; O, oleic acid; L, linoleic acid; $\mathrm{A}$, arachidic acid; B, behenic acid. 
acid composition of the oil (Martínez-Force et al., 2009). However, while different distributions have been reported for oils from different species, no systematic studies of the impact of this parameter on the physical properties of oils have been carried out to date. The oils studied here were grouped into three series containing about 27,30 and $34 \%$ of total saturated fatty acids, and they correspond to different oils and fats that could be obtained from high-oleic high-stearic sunflower mutant seeds. These oils are of great interest because they are an alternative to cocoa butter and other tropical fats as a source of high-stearic disaturated TAGs (Salas et al., 2009). Although these oils have a similar fatty acid composition, they contain different TAG species, as seen in Table 2. To construct this table we considered that the disaturated TAG species were mostly of the saturated-unsaturated-saturated type. Previous studies on the saturated fatty acid content at the $s n-2$ position of sunflower oils indicated that this is a valid approximation (Martínez-Force et al., 2009) and thus, they were ordered according to their $\alpha$ values. Higher values of this parameter reflect more symmetry in terms of the saturated fatty acids and hence, a higher disaturated TAG content at the expense of other TAG species, mainly monosaturated like 1-stearoyl-2,3-oleoyl glycerol (StOO) or triunsaturated like trioleoyl glycerol (OOO). The most abundant disaturated TAG in these oils was 1,3-distearoyl-2-oleoyl-glycerol (StOSt), with lower amounts of 1-palmitoyl-3-stearoyl-2-oleoyl glycerol (POSt) or similar derivatives containing arachidic or behenic fatty acids that gave rise to 1-arachidoyl2-oleoyl-3-stearoyl glycerol (AOSt) or 1-behenoyl2-oleoyl-3-stearoyl glycerol (BOSt).

The effect of the fatty acid distribution in TAGs can be observed in thermograms showing the melting and crystallization curves of the oils (Figure 1 and 3). The melting profiles of these oils displayed two peaks at approximately 5 and $18^{\circ} \mathrm{C}$, whose relative dimension changed in function of the $\alpha$ values. Moreover, an additional signal appeared at lower temperatures $\left(-5^{\circ} \mathrm{C}\right)$ in the series 3 oils. There was a clear increase in the higher temperature signal in series 1 and 2 oils, evident at the expense of the lower temperature peak and as reflected by the values of $\alpha$. This was due to the increase in disaturated TAGs that display higher melting points than monosaturated and triunsaturated ones. This effect has a direct impact on the solid fat content curves obtained by the integration of the melting thermograms (Figure 2), where the oils with the higher $\alpha$ coefficients displayed the highest solid contents during the melting interval of the oil from $-10{ }^{\circ} \mathrm{C}$ to $25^{\circ} \mathrm{C}$. This situation differed in series 3 oils, which represent combinations of TAGs that are not usually found in natural oils. These oils have weak TAG symmetry and their high levels of saturated fatty acids reflect a larger proportion of monosaturated

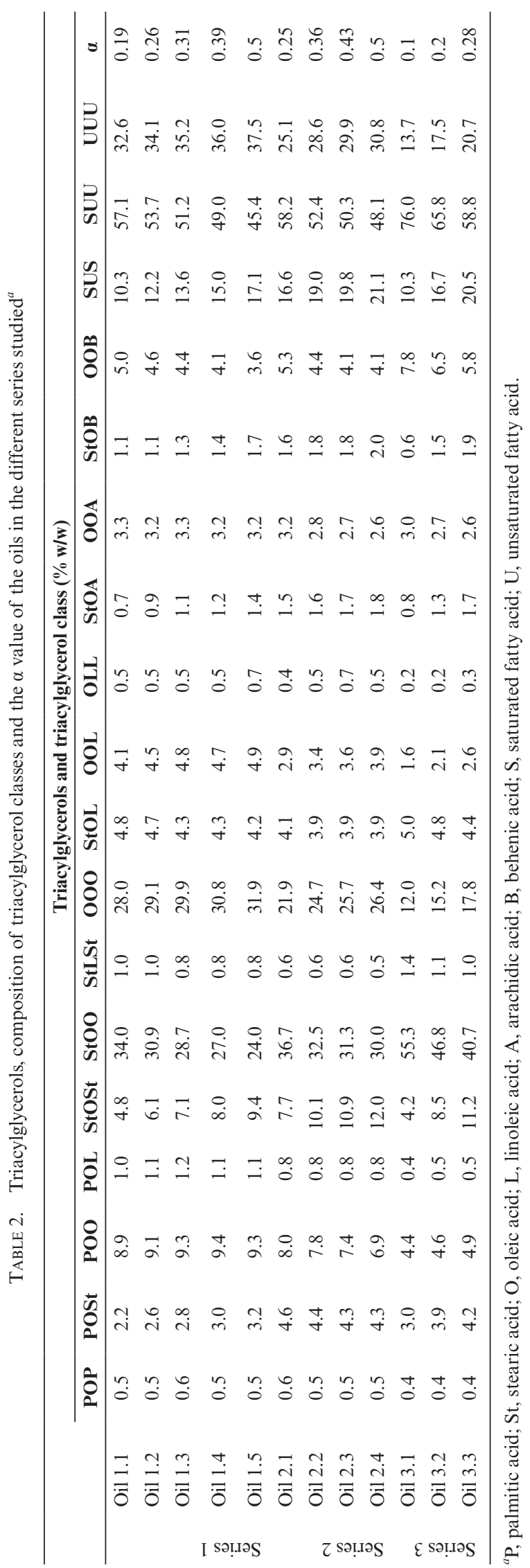



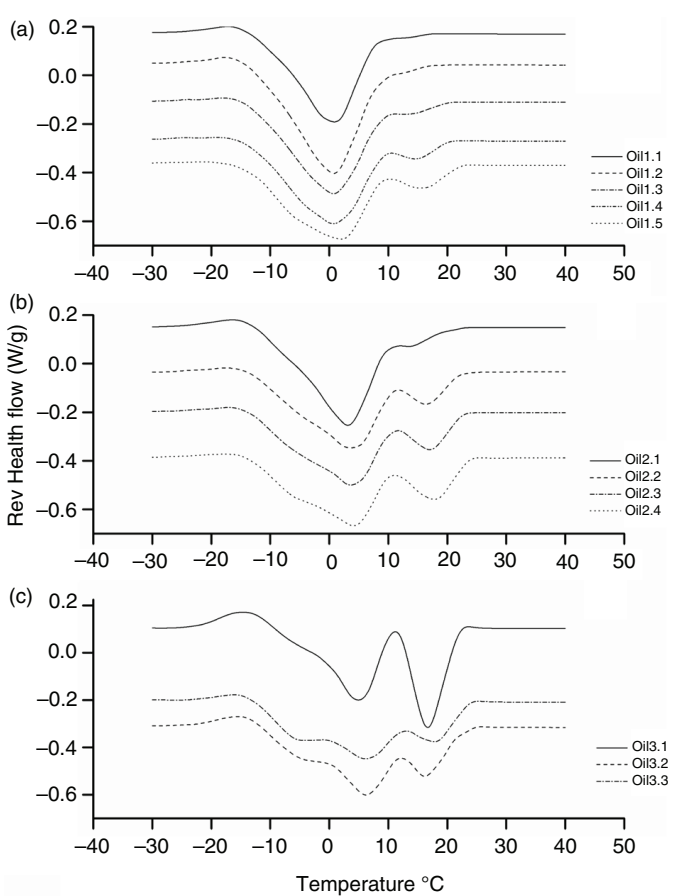

FIGURE 1. Melting profiles of the oils described in Tables 1 and 2, representing the oils in series 1,2 and 3 shown in graphs A, B and C, respectively. The lines corresponded to the oils with different $\alpha$ values as indicated.
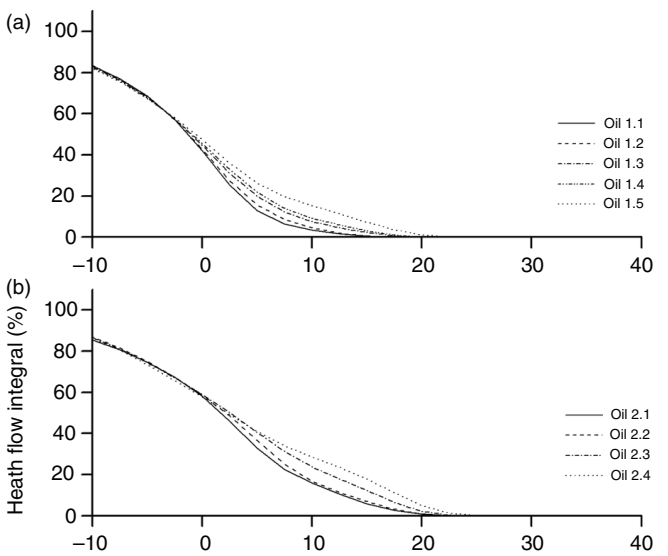

(c)

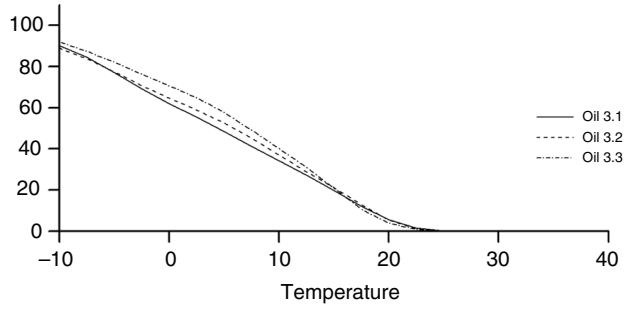

Figure 2. Curves of the solid contents resulting from the integration of the melting profiles obtained from the oils described in Tables 1 and 2. Series 1,2 and 3 are represented in graphs A, B and C, respectively and the lines correspond to the oils with different $\alpha$ values as indicated.
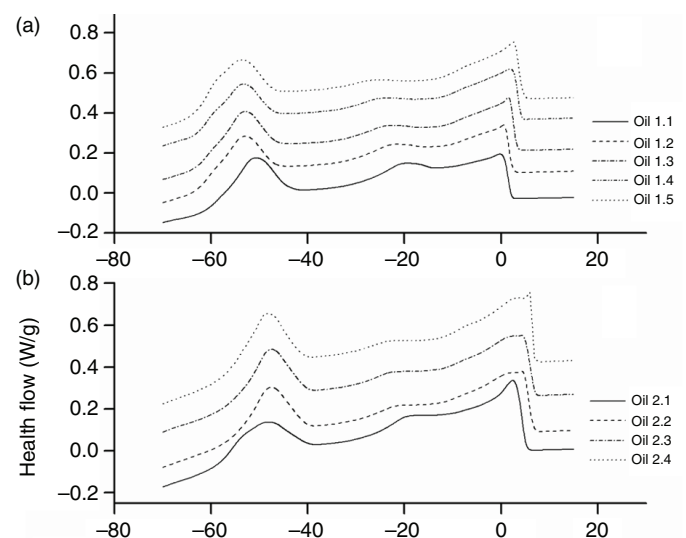

(c)

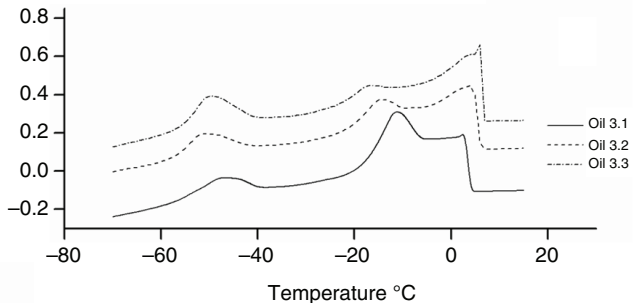

FIGURE 3. Crystallization profiles of the oils described in Tables 1 and 2. Series 1,2 and 3 are represented in the graphs $\mathrm{A}, \mathrm{B}$ and $\mathrm{C}$, respectively and the lines correspond to the oils with different $\alpha$ values as indicated.

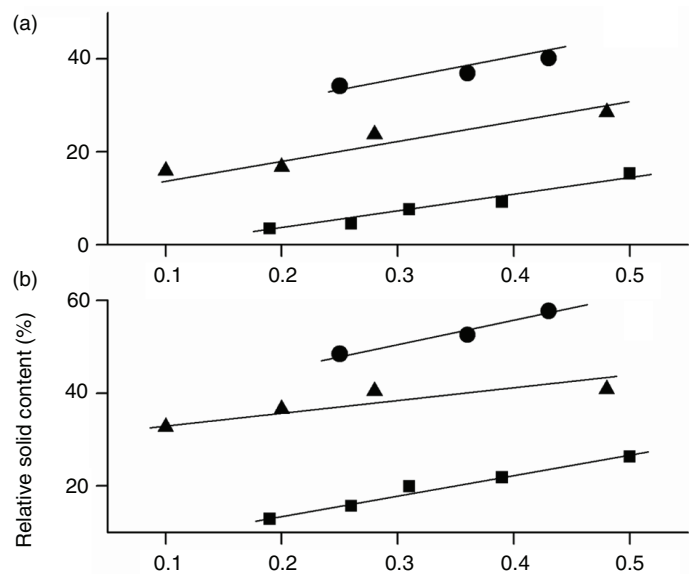

(c)

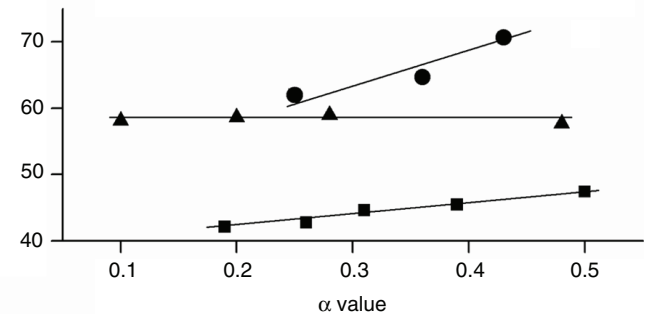

FIgURE 4. Relationship between the $\alpha$ values and the solid contents of the oils described in Tables 1 and 2 at three different temperatures: $-5^{\circ} \mathrm{C}(\mathrm{A}), 5^{\circ} \mathrm{C}(\mathrm{B})$ and $15^{\circ} \mathrm{C}(\mathrm{C})$. Plots corresponded to series $1(-\boldsymbol{-}-)$, series $2(-\mathbf{\Delta}-)$ and series $3(-\bullet-)$. 
TAGs (mainly StOO) at the expense of triunsaturated (like OOO) and disaturated TAGs. As the value of $\alpha$ increases, so does the level of triunsaturated and disaturated TAGs. Nevertheless, the higher disaturated fatty acid content of these oils assures they have the maximum solid content.

The distribution of fatty acids within TAGs also determines their crystallization behavior, an aspect that is important in many food products such as margarine, chocolate, butter and spreads. Thus, the complex behavior of some fats in terms of crystallization, polymorphic transformation, crystal morphology and aggregation depends directly on the properties of their TAGs (Foubert et al., 2006; Foubert et al., 2007, De Graef et al., 2012). The effects of different tristearin (StStSt) and StOSt ratios in TAGs on the crystallization behavior of different fat blends with the same fatty acid composition has been studied (Vereecken et al., 2009). Accordingly, StStSt does not appear to exert a seeding effect on the other TAGs present in the TAG mixture, unlike fats containing tripalmitin and dipalmitoyl glycerol. The present study did not use fat blends containing trisaturated TAGs since they were not present in highly saturated sunflower oils. To study crystallization behavior we applied a temperature ramp from 30 to $-70{ }^{\circ} \mathrm{C}$ and examined the resulting heat flow (Figure 3). In the three oil series studied, three exothermic signals were evident at approximately 5, -20 and $-50{ }^{\circ} \mathrm{C}$, corresponding to fractionated crystallization of different TAG species. The temperatures at which crystallization started were in function of the value of the $\alpha$ coefficient, meaning that oils with a higher symmetry coefficient, and therefore a higher disaturated content, started to solidify at higher temperatures. This indicated that the higher content of disaturated TAGs forced the crystallization of the oil at higher temperatures and as such, oils with a higher symmetry will tend to form crystals at higher temperatures than oils with lower $\alpha$ coefficients.

\section{CONCLUSIONS}

The thermal properties of a high-oleic highstearic oil series containing very similar fatty acid compositions changed in function of the distribution of saturated fatty acid in the TAGs. At saturated fatty acid concentrations of $30 \%$ or less, more symmetry in the distribution of saturated fatty acids involves a greater content of solids at temperatures from 0 to $20{ }^{\circ} \mathrm{C}$ and crystallization at higher temperatures (see Fig. 4, which shows the content of solids in the oils of the different series at 3 different temperatures). The content of solids tends to increase when the saturated fatty acids are more symmetrically distributed between the external TAG positions. These changes tended to be less noticeable at lower temperatures in series
1 and 2, whereas there was still a high degree of variation in the solid content in series 3 oils, probably since the changes in the $\alpha$ coefficient in this saturated fatty acid content involved more abrupt modifications in the TAG compositions of the oils. The physical properties of the oils studied clearly depend largely on the distribution of fatty acids in the TAGs, as well as on the fatty acid composition itself. Moreover, the $\alpha$ coefficient may be valid to quantify this distribution in terms of the symmetrical distribution of saturated fatty acids between the external positions of TAGs.

\section{ACKNOWLEDGMENTS}

This work was supported by the MICINN (AGL2008-01086), FEDER and Advanta Seeds.

\section{REFERENCES}

Carelli A, Cert A. 1993. Comparative study of the determination of triacylglycerol in vegetable oils using chromatographic techniques. J. Chromatogr. A. 630, 213-222. http://dx.doi. org/10.1016/0021-9673(93)80458-K

De Graef V, Vereecken J, Smith KW, Bhaggan K, Dewettinck K. 2012. Effect of TAG composition on the solid fat content profile, microstructure, and hardness of model fat blends with identical saturated fatty acid content. Eur. J. Lipid Sci. Technol. 114, 592-601. http://dx.doi.org/10.1002/ ejlt. 201100215

Fernández-Moya V, Martínez-Force E, Garcés R. 2005. Oils from improved high stearic acid sunflower seeds. J. Agric. Food Chem. 53, 5326-5330. http://dx.doi.org/10.1021/ jf0503412

Fernández-Moya V, Martínez-Force E, Garcés R. 2000. Identification of triacylglycerol species from high-saturated sunflower Helianthus annuus. mutants. J. Agric. Food Chem. 48, 764-769. http://dx.doi.org/10.1021/jf9903861

Flickinger BD, Huth PJ. 2004. Dietary fats and oils: technologies for improving cardiovascular health. Curr. Atheroscler. Rep. 6, 468-476. http://dx.doi.org/10.1007/s11883-004-0088-4

Foubert I, Vereecken J, Smith KW, Dewettinck K. 2006. Relationship between crystallization behavior, microstructure, and macroscopic properties in trans containing and trans free coating fats and coatings. J. Agric. Food Chem. 54, 7256-7262. http://dx.doi.org/10.1021/jf060225e

Foubert I, Vereecken J, Smith KW, Dewettinck K. 2007. Relationship between crystallization behavior, microstructure, and macroscopic properties in trans containing and trans free filling fats and fillings. J. Agric. Food Chem. 55, 7793-7801. http://dx.doi.org/10.1021/jf070650n.

Garcés R, Mancha M. 1993. One-step lipid extraction and fatty acid methyl esters preparation from fresh plant tissues, Anal. Biochem. 211, 139-143. http://dx.doi.org/10.1006/ abio. 1993.1244

Gunstone FD. 2002. Vegetable Oils in Food Technology, CRC Press. Boca Raton, Florida.

Legrand P, Rioux V. 2015. Specific roles of saturated fatty acids: Beyond epidemiological data. Eur. J. Lipid Sci. Technol. 117, 1489-1499. http://dx.doi.org/10.1002/ ejlt. 201400514

List GR. 2004. Decreasing trans and saturated fatty acid content in food oils. Food Technol. 58, 23-31. ISSN 0015-6639

Marangoni AG. 2002. Special issue of FRI - crystallization, structure and functionality of fats. Food Res Int. 35, 907908. http://dx.doi.org/10.1016/S0963-9969(02)00152-7

Martínez-Force E, Ruiz-López N, Garcés R. 2004. The determination of the asymmetrical stereochemical distribution of fatty acids in triacylglycerols. Anal. Biochem. 334, 175-182. http://dx.doi.org/10.1016/j.ab.2004.07.019 
Martínez-Force E, Ruiz-López N, Garcés R. 2009. Influence of specific fatty acids on the asymmetric distribution of saturated fatty acids in sunflower Helianthus annuиs L. triacylglycerols. J. Agric. Food Chem. 57, 1595-1599.

Narine SS, Marangoni AG. 1999. Relating structure of fat crystal networks to mechanical properties: A review. Food Res Int. 32, 227-248. http://dx.doi.org/10.1016/ S0963-9969(99)00078-2

Ohlrogge J, Browse J. 1995. Lipid biosynthesis. Plant Cell. 7, 957-970. http://dx.doi.org/10.1105/tpc.7.7.957

Ping Tan C, Nehdi IA. 2015. DSC Analysis of vegetable oils - Relationship between thermal profiles and chemical composition in Chiavaro E (Ed.) Differential scanning calorimetry - Applications in fats and oils technology. CRC Press, Boca Raton, FL, pp. 3-26.

Pleite R, Martínez-Force E, Garcés R. 2006. Increase of the stearic acid content in high-oleic sunflower Helianthus annuus. seeds. J. Agric. Food Chem. 54, 9383-9388. http:// dx.doi.org/10.1021/jf061654f

Salas JJ, Bootello MA, Martínez-Force E, Garcés R. 2009. Tropical Vegetable Fats and Butters: Properties and New Alternatives. OCL Oleagineux 16, 254-258. http://dx.doi. org/10.1051/ocl.2009.0278

Samyn P, Schoukens G, Vonck L, Stanssens D, Van den Abbeele H. 2012. Quality of Brazilian vegetable oils evaluated by (modulated) differential scanning calorimetry. J. Therm.
Anal Calorim. 110, 1353-1365. http://dx.doi.org/10.1007/ s10973-011-2132-2

Santinelli F, Daminani P, Christie W. 1992. The triacylglycerol structure of olive oil determined by silver ion high performance liquid chromatography in combination with stereospecific analysis. J. Am. Oil Chem. Soc. 69, 552-556. http:// dx.doi.org/10.1007/BF02636107

Smith KW, Bhaggan K, Talbot G. 2013. Phase behavior of symmetrical monounsaturated triacylglycerols. Eur. J. Lipid Sci. Technol. 115, 838-846. http://dx.doi.org/10.1002/ ejlt.201300035

Takagi T, Ando Y. 1995. Stereospecific analysis of triacylsn-glycerols by chiral high performance liquid chromatography. Lipids 26, 542-547. http://dx.doi.org/10.1007/ BF02536601

Van der Wal RJ. 1960. Calculation of the distribution of the saturated and unsaturated acyl groups in fats, from pancreatic lipase hydrolysis data. J. Am. Oil Chem. Soc. 37: 18-20. http://dx.doi.org/10.1007/BF02630816

Vereecken J, Foubert I, Smith KW, Dewettinck K. 2009. Effect of SatSatSat and SatOSat on crystallization of model fat blends. Eur. J. Lipid Sci. Technol. 111, 243-258. http:// dx.doi.org/10.1002/ejlt.200800150.

Wassell P, Young NWG. 2007. Food applications of trans fatty acid substitutes. Int J Food Sci Technol. 42, 503-517. http:// dx.doi.org/10.1111/j.1365-2621.2007.01571.x 